\title{
Women (and Men) on the Move: Scots in the English North c. 1440
}

\section{Judith M. Bennett}

\begin{abstract}
Alien subsidies suggest that many men and few women immigrated to England between 1440 and 1487. This article examines the one exception to this pattern: the large numbers of Scotswomen assessed as aliens in Cumberland, Westmorland, and Northumberland in 1440. It considers why so many women are found in these particular returns, what we can know about them, and how this knowledge might change our histories of women, labor, and mobility in both Scotland and England.
\end{abstract}

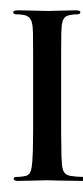

$\mathrm{n}$ the mid-fifteenth century, somewhere between 1 and 2 percent of England's inhabitants (about 6 percent in London) were immigrants. Most-about three-quarters - came from a handful of nearby realms: from France, Scotland, and Ireland, or from the Low Countries and German states (often collectively called "the Dutch"). ${ }^{1}$ Many settled, or at least were recorded by head-counters, near to their points of entry-Scots in the north of England, Irish in the southwest, Dutch in East Anglia, French all along the south coast, and a great variety in London. The vast majority of these immigrants were men or boys - about 85 non-native-born males reported for every 15 females. Real numbers were not as out of kilter as these reported numbers, for enumerators rarely recorded wives and probably under-recorded unmarried women (a common problem in medieval tallies). Yet even allowing for these slippages, the sex ratio of England's immigrants was dramatically askew. Many different sorts of "aliens" moved to England in the fifteenth century, but most were men and boys.

This essay examines the one exception to this rule: the plethora of immigrant women who were recorded in 1440 as living and working in Cumberland, Westmorland, and Northumberland. Encompassing England's northern marches with

Judith M. Bennett taught at the University of North Carolina at Chapel Hill and the University of Southern California. She thanks Elizabeth Ewan, Cynthia Herrup, Maryanne Kowaleski, Jonathan Mackman, Shannon McSheffrey, Mark Ormrod, Sarah Rees Jones, Angus Winchester, and Christopher Whittick for their thoughtful comments on drafts, as well as the anonymous readers for the Journal of British Studies and the audience at a session on immigration at the North American Conference on British Studies annual meeting (November 2016). She also thanks Giles Darkes for preparing the maps.

${ }^{1} \mathrm{My}$ analysis draws extensively on the online database England's Immigrants 1330-1550: Resident Aliens in the Later Middle Ages (hereafter EIDB), https://www.englandsimmigrants.com/. In citing individual cases, I have used record numbers from the EIDB, which will send readers to case summaries and archival citations. To reach a specific case, use this link and replace $\mathrm{xxx}$ with the record number: https://www.englandsimmigrants.com/person/xxx (it is not possible to search the database by record number). I have silently modernized English quotations throughout. For population estimates, see the background section of the EIDB, but my figures also reflect Jonathan Mackman's latest estimates of an overall proportion of aliens (not including the Welsh) as high as 1.5 percent (Mackman, personal communication). 
Scotland, these counties were part of a common Anglo-Scottish borderland of shared culture, custom, law, and lordship, and they were riven with battles, raids, and rebellions during the Scottish Wars of Independence (1296-1357) and long thereafter. ${ }^{2}$ Shaken by warfare in 1436 and steadied by a nine-year armistice in 1438, they were tense in 1440 but relatively settled. In that year, women-almost all of them Scotswomen-accounted for 46 percent, 43 percent, and 32 percent of reported immigrants in Westmorland, Cumberland, and Northumberland, respectively. Map 1 shows the extraordinary extent of their presence in the North, as compared with the rest of the realm.

Because Lancashire's returns are inadequate and no reports were required from the liberties of Durham and Chester, it is difficult to trace how the presence of women might have withered with distance from the border. But figures for the east coast-30 percent females in the North Riding of Yorkshire, 27 percent in the East Riding of Yorkshire, 23 percent in the incomplete Lincolnshire returnssuggest just that. Inland parts of the North-the West Riding and Nottinghamshire-attracted fewer immigrants, fewer Scots (and more French), and fewer women. But the North still stands out. We have no or little information for Oxfordshire, Derbyshire, and Lancashire, but only a handful of jurisdictions in the rest of England reported more than the usual proportion of female immigrants. Most of these-London at 26 percent, Middlesex at 21 percent, Surrey at 19 percent, Gloucestershire at 24 percent-derived their impressive numbers from large urban populations. Warwickshire (without returns from Coventry) and Bedfordshire were the only other jurisdictions reporting unusually high proportions of female immigrants, at 19 percent and 17 percent respectively. It seems that Scotswomen, just like native-born women within England, were attracted to cities and towns. Yet they were especially attracted to England's North.

\section{MEDIEVAL SOURCES AND MODERN DATABASES}

We know about these immigrants because of an entirely new tax, an alien subsidy created amid xenophobic agitation in the waning years of the Hundred Years' War. ${ }^{3}$ Anti-alien antagonism was not new in the 1430 s, but it was aggravated in

\footnotetext{
${ }^{2}$ As Cynthia Neville concisely put it, the northern marches were "confined to-though not contiguous with - the northernmost shires of Northumberland, Cumberland and Westmorland." Cynthia J. Neville, Violence, Custom and Law: The Anglo-Scottish Border Lands in the Later Middle Ages (Edinburgh, 1998), 185. I hereafter adopt an English point of view by referring to these counties as "the borders" or "border counties."

${ }^{3}$ The historiography on aliens in medieval England is deep and rich. For recent work, see especially Bart Lambert and W. Mark Ormrod, "Friendly Foreigners: International Warfare, Resident Aliens and the Early History of Denization in England, c.1250-c.1400," English Historical Review 130, no. 542 (March 2015): 1-24; Maryanne Kowaleski, "Alien' Encounters in the Maritime World of Medieval England," Medieval Encounters 13, no. 1 (2007): 96-121; R. B. Dobson, "Aliens in the City of York during the Fifteenth Century," in England and the Continent in the Middle Ages: Studies in Memory of Andrew Martindale, ed. John Mitchell (Stamford, 2000), 249-66; J. L. Bolton, "Irish Migration to England in the Late Middle Ages: The Evidence of 1394 and 1440," Irish Historical Studies 32, no. 125 (May 2000), 1-21; J. L. Bolton, ed., The Alien Communities of London in the Fifteenth Century: The Subsidy Rolls of 1440 and 1483-4 (Stamford, 1998); Keechang Kim, Aliens in Medieval Law: The Origins of Modern Citizenship (Cambridge, 2000); Claire Sponsler, "Alien Nation: London's Aliens and Lydgate's Mummings
} 


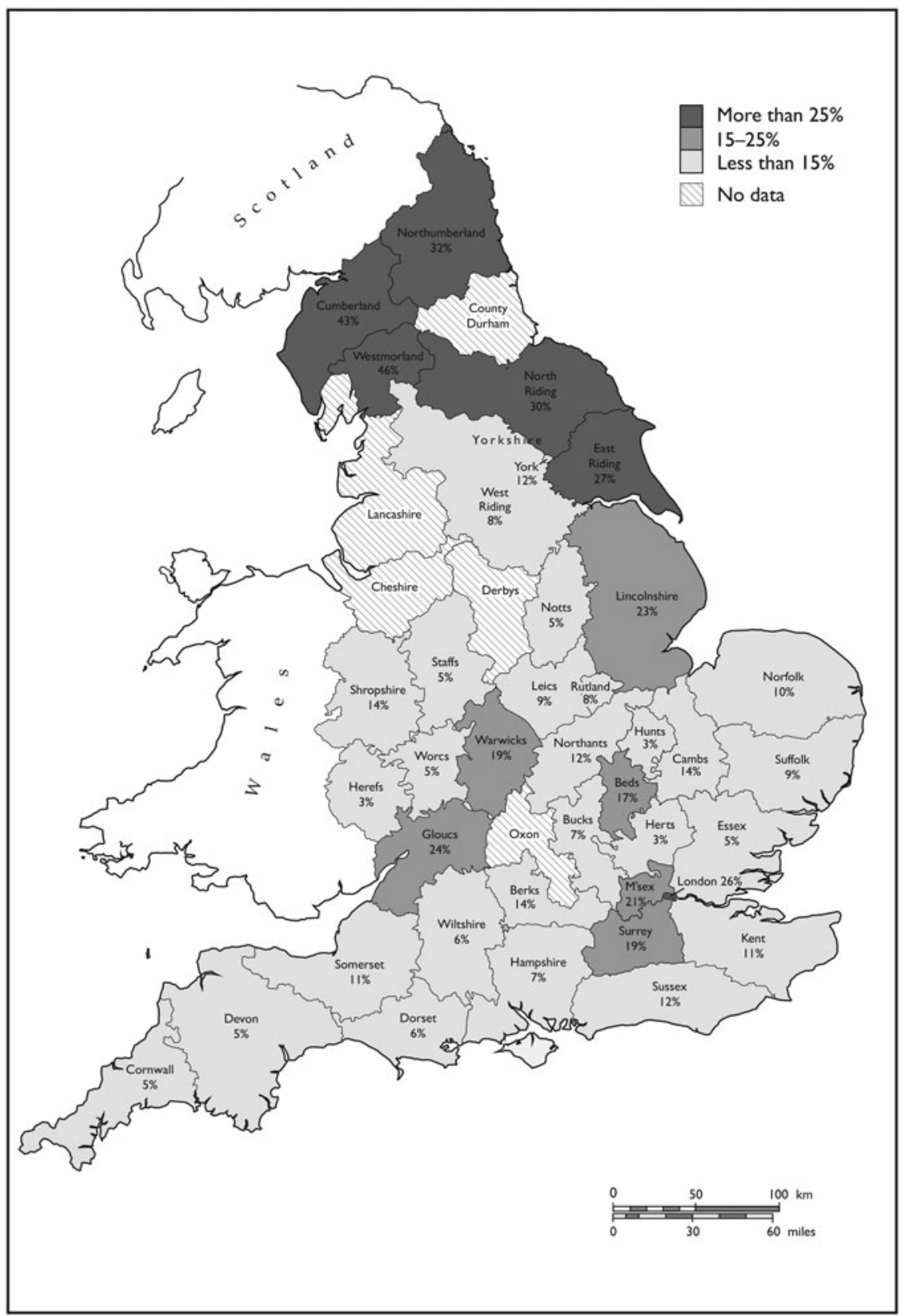

Map 1-Proportions of Females among Aliens Taxed in 1440. These realm-wide figures are derived from EIDB data for the first collection of the 1440 tax. 
that decade by English setbacks in France and roundly expressed both in petitions sent to Parliament and in a popular poem, "The Libelle of Englyshe Polycye," written in 1436 and much circulated thereafter. Aliens were deemed unwelcome, unsafe, unduly prosperous, unassimilated, and, most critically for this project, undertaxed. ${ }^{4}$ In the autumn of 1439 , Parliament responded by imposing new restrictions on alien merchants, and early in 1440, it also imposed a new tax on aliens in support of naval defenses (a particularly apposite designation). Designed to run for three years (with two collections each year), the new levy took from all non-native-born adults (over twelve years of age) in the realm either 16d. (for householders) or $6 \mathrm{~d}$. (for non-householders). ${ }^{5}$ Five main groups escaped the tax: the Welsh, the regular clergy, non-native women married to English or Welsh men, any person who had purchased a letter of denization, and, of course, aliens in exempt liberties. This alien tax was renewed and revised over the course of nearly fifty years, but the first collection in 1440 was by far the most comprehensive.

The Exchequer records produced by the 1440 tax were first investigated in 1957 by Sylvia Thrupp. She commented on only three aspects of the northern returns: how few aliens in the North actually paid the tax, how many of them were footloose vagabonds, and how much Scots predominated among them. ${ }^{6}$ She did not mention the unusual numbers of alien women in the northern border counties, and although historians since have noted these women, they have not paused over them. The recent digitalization of the alien subsidies in the database England's Immigrants 1330-1550 (EIDB), funded by the Arts and Humanities Research Council and now freely available online, has changed forever, and for the better, what we can know about these women-and about aliens in premodern England more generally. Thanks to the EIDB, we can now say, with uncommon confidence, that the first collection of the alien tax in 1440 netted information about 15,901 individuals who were not native-born; that 1,133 aliens were reported as living in Cumberland, Westmorland, and Northumberland; that virtually all of these were Scots; and that the count included 717 men, 409 women, and seven persons of unknown gender.

This is heady precision, especially for medieval records, and historians of English immigration will be forever grateful to W. Mark Ormrod (principal investigator), Jonathan Mackman (research fellow), and their team of research assistants.

\footnotetext{
for the Mercers and Goldsmiths," in The Postcolonial Middle Ages, ed. Jeffrey Jerome Cohen (Basingstoke, 2000), 229-42. Among earlier studies, see especially T. H. Lloyd, Alien Merchants in England in the High Middle Ages (Brighton, 1982); Nellie J. Kerling, "Aliens in the County of Norfolk, 1436-85," Norfolk Archaeology 33, no. 2 (1963): 200-15; Sylvia Thrupp, "Aliens in and around London in the 15th Century," in Studies in London History Presented to Philip Edmund Jones, ed. A. E. J. Hollaender and William Kellaway (London, 1969), 251-72, and Sylvia Thrupp, "A Survey of the Alien Population of England in 1440," Speculum 32, no. 2 (April 1957): 262-73; Alwyn A. Ruddock, "Alien Merchants in Southampton in the Later Middle Ages," English Historical Review 61, no. 239 (January 1946): 1-17; Alice Beardwood, Alien Merchants in England, 1350-1377: Their Legal and Economic Position (Cambridge, MA, 1931).

${ }^{4}$ Bolton, Alien Communities of London, 35-40.

5 "Henry VI: November 1439," in Parliament Rolls of Medieval England, ed. Chris Given-Wilson et al. (Woodbridge, 2005), British History Online, http://www.british-history.ac.uk/no-series/parliament-rollsmedieval/november-1439, accessed 19 March 2016. For further background, see R. A. Griffiths, The Reign of King Henry VI (Stroud, 1998), 551-61.

6 Thrupp, "A Survey of the Alien Population."
} 
But databases are not any more transparent than documents, and they must also be used with care. While focusing on the historical problem posed by the peculiar abundance of female immigrants in the North in 1440, this essay also provides a test case for the methodological possibilities of the EIDB. ${ }^{7}$ I was fortunate to have taken extensive notes from the Exchequer returns for Cumberland, Westmorland, and Northumberland a decade before the EIDB came online. I therefore knew the archival record well, but I had also stumbled up against its limitations, particularly its unwieldy bulk and its need for context within the larger realm. With impressive efficiency, the EIDB resolved these challenges, providing instant, precise, and reliable answers to my questions about northern trends and how they differed from the rest of England.

But the EIDB, like any database, must nonetheless be approached with care. It is easy, for example, for users to mistake its references-it contains some 64,000 names-for individuals; this is not so. Many individual aliens are counted twice or more in the EIDB, and although some names are linked across records within the database, others are not. To put this another way, the EIDB contains 64,000 references, but it reports on many fewer than 64,000 individuals. The best way to avoid duplication is to focus on a single set of nominal lists, and I have done just that in this essay, using only the first collection of the 1440 tax. Yet my strategy introduces its own limitations. First, I have not sought to trace individuals over subsequent years of tax collection. Given the challenges of linking persons who were vaguely named-the tax includes, for example, many dozens of taxpayers named "Joan Scot" and "John Scot"- this might have been a fool's errand, and in the event, very few individuals from 1440 have been traced in later taxes (the EIDB reports on only fourteen recurrences). Second, my focus on a single collection of the tax precludes plugging gaps in one return with information from another. Lincolnshire, for example, is poorly covered in the surviving returns for the first collection in 1440, but much more satisfactory returns (necessarily ignored here) survive for later collections. Sarah Rees Jones, who has examined the northern returns for the entire three-year run of the first alien subsidy, provides a comparative example of the advantages of an alternative approach. ${ }^{8}$

Also, of course, the EIDB can tabulate only what the records provide. If returns were lost, jurisdictions exempt, or people overlooked, the EIDB reports accordingly, so that areas with no or few aliens in the EIDB sometimes tell us more about bureaucratic or archival holes than about circumstances on the ground. In tabulating the alien taxes, the EIDB relies on nominal returns, not fiscal sums, and it therefore does not provide a fully accurate tally of taxpayers. Only 15,901 individual aliens are identified in the EIDB for the first collection of the 1440 tax, but Mackman has calculated from summary accounts that 16,878 persons were actually assessed for the tax. ${ }^{9}$ For the purposes of this essay, of course, individuals tallied are more

\footnotetext{
${ }^{7}$ For a review of the EIDB, see Justin Colson, "Review of Web Databases for Late Medieval Social and Economic History: England's Immigrants and the Overland Trade Project," http://www.history.ac.uk/reviews/ review/1820, accessed 12 April 2016.

${ }^{8}$ Sarah Rees Jones, "Scots in the North of England: The First Alien Subsidy, 1440-43," in Resident Aliens in Later Medieval England, ed. W. Mark Ormrod, Nicola McDonald, and Craig Taylor (Turnhout, forthcoming).

${ }^{9}$ Jonathan Mackman, personal communication.
} 
important than assessed totals, so my analyses rely on the lower figure, derived from nominal returns and reported in the EIDB.

As a source of revenue, the subsidy was always a disappointment, probably yielding a mere $£ 400$ pounds in 1440 , its most successful year. Once the shock of the new levy became routine, some aliens surely learned how to evade tax officers, but the decline was also the result of administrative lethargy. The parliamentary grant included a critical loophole that allowed sheriffs to escape liability for the unpaid taxes of aliens who had died or moved between assessment and collection. Even in 1440, some sheriffs-including those in Cumberland and Westmorland-reported that whole groups of aliens had moved away and not paid the tax. Perhaps so, or perhaps sheriffs were not bothering to collect what was due, or perhaps they were collecting the tax, keeping it, and reporting it as unpaid. These administrative problems only increased over time, so much so that, as Mackman has suggested, the tax's revenues might eventually have not even covered the cost of its administration. ${ }^{10}$

Fortunately, most of these problems were still in the future in 1440, when the subsidy was new and its administration relatively robust. For most counties in 1440, we have long, plausible lists of aliens. The process of tax collection produced these lists twice over-first, during assessment of liability for the tax (mostly executed by justices of the peace and constables), and second, during the actual collection of the tax (mostly done by sheriffs). Both sorts of lists identify individuals by name, although naming practices were uneven: some people received ad hoc surnames, often based on their national origin (for example, "Mary Scot" or "Arnold Dutchman"); servants were sometimes identified by their masters or mistresses (for example, "John servant of Thomas Smith," rather than "John Lidale servant of Thomas Smith"); and a few were identified simply by employment (for example, "a maidservant, name unknown, of Thomas Smith"). All individuals were sorted into two groups-householders and non-householders-based on tax liability. Some were additionally identified by occupation or country of origin, although that information was not required by writ. And, in the case of nominal lists used for collection, we sometimes know who actually paid the tax and who (at least according to what was reported to the Exchequer) had moved or died before paying.

These administrative practices establish southern limits for tracking the movement of Scots into England in 1440. Aliens in the palatinates of Durham and Cheshire escaped the subsidy, and the same was de facto true for those in Lancashire, which reported all of five taxable aliens for the entire county. For Cumberland, we have a return that listed 319 aliens, most of whom, it was claimed, had moved between assessment in early August and collection sometime before mid-November. Most were fully named with both forename and surname; the vast majority of non-householders were identified as servants of specific masters or mistresses; and only a few householders were identified with occupations. The return for Westmorland (undated, but likely compiled between July and September) lists 105 aliens, providing much the same sort of information as in Cumberland. The Northumberland returns report on more people but provide less information about them. Almost

${ }^{10}$ Jonathan Mackman, "Was It Really Worth the Effort? The Administration of the Alien Subsidies, 1440-87," paper presented at Medieval Merchants and Money conference, University of London, London, 7 November 2013 (typescript provided by author). 
all of the Northumberland lists derive from initial assessments conducted in April or June, with the result that we know nothing about how most of the 710 aliens reported in the county might have moved-or been reported to have movedbetween then and collection. ${ }^{11}$ We also know much less about occupations in Northumberland, with information given for only one-third of taxpayers. Also, about fifty entries for Northumberland are missing or too damaged to recover.

The great preponderance of Scots in the realm was reported in these northern borders - at least 73 percent, using the cautious standards for national origin applied in the EIDB. More importantly for this project, the alien community in the North in 1440 was, to all intents and purposes, a community of expatriate Scots. Constables in Northumberland regularly commented on national origins, tabulating a Fleming, a Dutchman, two Irish (who might have been Gaelic Scots), and 598 Scots. Of the remaining 108 individuals taxed in the county, almost all derive from a single return for Newcastle in which eight persons were surnamed "Scot," but the rest were recorded without any indication of national origin. Westmorland reported two Frenchmen, three Irish (again, possibly Gaelic Scots), and 68 aliens either identified as Scottish or surnamed "Scot." Cumberland gave the surname "Scot" to 139 of its 319 aliens and reported no aliens from anywhere else. Nationbased surnames are usually a reliable indicator of origins (for others, as well as for Scots), but even with such surnames included, these returns leave several hundred aliens unidentified as to national origin. Some other surnames suggest Scottish origins (for example, Rotherford, Gibson, Atkinson), but most names were unexceptional (for example, Patrick Sharp, Robert and William Pule, Matilda Hyne, Alice Halyday). Given the preponderance of Scots among aliens of stated origin in the northern border counties (99 percent), most, if not all, of these aliens without stated origin must have been Scots. They have been counted as such in all that follows. ${ }^{12}$

All three counties have locational black holes-areas where either no Scots lived or none were reported in extant records. Some of these gaps were jurisdictional-areas where no Scots were reported because none could be taxed: in Cumberland, the area south of Workington was part of the liberty of Copeland, and in Northumberland, the area south of Berwick, where some Scots surely settled, included two districts, around Norham and Lindisfarne, that were outlying enclaves of the liberty of Durham. Almost no aliens were listed in upland regions, but it is anyone's guess whether this is because Scots did not venture into these areas or because constables did not bother to list them. Even in the lowlands, some areas reported remarkably few aliens; for example, an empty belt stretches across the center of Northumberland, with many Scots found in the county's north and south but not its middle.

${ }^{11}$ The EIDB reports 709 named aliens in the county but overlooked John Watson in The National Archives (hereafter TNA), E 179/158/74, m. 2d. I added him to all the calculations that follow.

${ }^{12}$ Others agree that almost all aliens in the northern returns were Scottish (whether explicitly identified as such or not). See David Ditchburn, "Anglo-Scottish Relations in the Later Middle Ages: The Other Side of the Coin," in The Plantagenet Empire, 1259-1453, ed. Peter Crooks, David Green, and W. Mark Ormrod (Donington, 2016), 310-34; and Rees Jones, "Scots in the North." Differences in identification of immigrant Scots were jurisdictional, not substantial: some officers identified Scots by national origin; some used the surname "Scot"; and some merely provided names, noting national origin only for the few non-Scots who "were exceptions among an alien community that was again overwhelmingly Scottish" (Ditchburn, "Anglo-Scottish Relations," 322). 
Of course, we cannot know how many people were simply overlooked in places that were surveyed. Some people may have hidden, moved away, or claimed to be younger than they were; others were too poor or too transient to matter; and as in most medieval lists, women were likely undercounted. The identification of Scots as Scots must have presented some particular challenges. Some were surely known by employers, friends, or neighbors as Scottish-born, and this was indubitably a characteristic that mattered: the administration of the cross-border court of the march-with English juries for English offenders and Scots juries for Scots offenders - had long encouraged ready distinctions between English and Scot, especially for men. ${ }^{13}$ But what about Scots who wanted to pass as English, either to avoid the tax or for other reasons? A constable who asked jurors in, say, Carlisle, to identify all local Scots might have received confused and contradictory advice. It could have been easy for local men to know that a person's accent was not native to the town, but less easy to place origin-perhaps the accent was from Dumfries, or perhaps Bowness-on-Solway, or perhaps Brampton. At least some Scots surely passed as English and escaped the tax. Once beyond the northern counties, Scots could more easily dodge alien taxes and anti-Scottish prejudice by explaining their distinctive dialects and customs as northern English, with perhaps no one to say otherwise. ${ }^{14}$ The tiny numbers of Scots recorded in most southern counties in 1440 might therefore be especially incomplete. All told, then, the returns for the alien tax are, like all historical sources, flawed and tricky, but they do reliably tell us, for the communities covered, who was publicly identified as an alien when the king's men came asking in the summer of 1440 .

\section{SCOTS IN THE ENGLISH NORTH}

We have incomplete or garbled information for a few of the 1,125 Scots reported in the northern border counties in 1440; when these are winnowed out, 1,119 remain, of whom 409 were female ( 37 percent). In the returns sent to the Exchequer, gender mattered (women were often listed after men), but household status (and thus, tax status) mattered more. Clerks sorted aliens out of their domestic units to create two discrete lists of householders and non-householders. The results of their efforts are shown in table 1.

The category of untaxed wives is a quirk of the assessment process. The initial parliamentary grant allowed assessors to ignore married women among alien populations by providing that wives of native men would not be taxed and saying nothing whatsoever about wives of alien men. In practice, wives were not taxed, regardless of the national origins of their husbands. ${ }^{15}$ Yet a few constables nevertheless took the trouble to report alien wives of alien men; in the realm as a whole in 1440, wives were reported for 15 percent of husbands (844 wives and 5493 male

\footnotetext{
${ }^{13}$ Neville, Violence, Custom and Law.

${ }^{14}$ Mackman reports that some later alien subsidies include successful appeals of Englishness made by persons assessed as Scots (personal communication). See also discussion in Ditchburn, "Anglo-Scottish Relations," 333.

${ }^{15}$ As always, there are exceptions; two wives of non-householding males in Cumberland were assessed for the tax: EIDB\#29702/29703 and 29733/29734.
} 
Table 1-Scots in the English North in 1440.

\begin{tabular}{lcccr}
\hline & Cumberland & Westmorland & Northumberland & Totals \\
\hline Male householders & 82 & 13 & 160 & $\mathbf{2 5 5}$ \\
Female householders & 14 & 0 & 26 & $\mathbf{4 0}$ \\
Male non-householders & 98 & 39 & 318 & $\mathbf{4 5 5}$ \\
Female non-householders & 123 & 47 & 159 & $\mathbf{3 2 9}$ \\
Untaxed wives & 0 & 0 & 40 & $\mathbf{4 0}$ \\
Totals & $\mathbf{3 1 7}$ & 99 & 703 & $\mathbf{1 1 1 9}$ \\
\hline
\end{tabular}

Note: The EIDB reports thirty-nine wives in Northumberland and forty untaxed persons. Joan Webster (EIDB\#6712) accounts for the difference, and I have included her in my count.

householders). No wives were recorded in Cumberland or Westmorland, but 40 wives were scattered across the Northumberland returns: none in some districts, one or two in others, and concentrations in Cowpen (four), Ponteland (four), and Newcastle (nine). If we consider only the two Northumbrian wards with fullest reporting on wives-Inner Ward and Newcastle - they suggest that about one-fifth of Scottish householders had Scottish wives (eight of forty-four male householders in Inner Ward, and nine of forty-two in Newcastle). Were all the other wives English-born? Or were many Scottish wives unreported? We cannot know. ${ }^{16}$ Perhaps only one in five married Scotsmen had Scottish wives, but this is surely a minimal figure: reporting was idiosyncratic, the numbers are small, and our information is incomplete (for example, at least a few male householders-those who were single or widowed-lived without wives). As to Scottish women married to English men, we know nothing. Because wives were reported so unsystematically (and not at all for the two western counties), I have set to one side the forty wives noted in Northumberland. But if wives had been consistently included in tax records, we would be able to see many more women among emigrant Scots in the North than the 37 percent reported in the tax; more than likely, the actual sex ratio of Scottish emigrants in northern England was close to equal.

The northern English counties to which these Scots had relocated by 1440 were not prosperous destinations. ${ }^{17}$ The population of the north in 1440 had not recovered from the Black Death; it was still half, or even less, of its level of a century earlier. Roads were few and poor, especially in the west (indeed, Cumbrian roads were so abysmal that English kings intent on invading Scotland usually marched their armies up the longer eastern route). ${ }^{18}$ Towns were also few and modest; in

\footnotetext{
${ }^{16}$ For more on aliens who married English spouses, see Andrea Ruddick's forthcoming "Immigrants and Inter-Marriage in Late Medieval England," in Ormord, McDonald, and Taylor, eds., Resident Aliens in Later Medieval England (Turnhout, forthcoming).

${ }^{17}$ For general introductions, see A. J. Pollard, North-Eastern England during the Wars of the Roses: Lay Society, War and Politics, 1450-1500 (Oxford, 1990); Angus J. L. Winchester, Landscape and Society in Medieval Cumbria (Edinburgh, 1987); and Angus J. L. Winchester, The Harvest of the Hills: Rural Life in Northern England and the Scottish Borders, 1400-1700 (Edinburgh, 2000).

${ }^{18}$ See especially Brian Paul Hindle, "Medieval Roads in the Diocese of Carlisle," Transactions of the Cumberland and Westmorland Antiquarian and Archaeological Society, 2nd. ser., 77 (1977): 83-95, and Brian Paul Hindle, "Roads and Tracks," in The Medieval English Landscape, ed. Leonard Cantor
} 
Northumberland, for example, these included only Newcastle, North Shields, Alnwick, and Berwick (which would return to Scottish hands between 1461 and 1482). Yet the economy was diverse and potentially robust-mixed farming and open fields in the lowlands; stock-raising (both sheep and cattle) and more dispersed settlement in the uplands; fishing; mining of coal and lead; salt-making; and the beginnings of a complex system of cattle-droving (both Scots and English cattle) towards southern markets. Between 1410 and 1430, the northern economy had bounced back strongly from the fourteenth-century ravages of climate change, disease, and war. ${ }^{19}$ This boom came to an abrupt halt in 1438-40, when all of England, but particularly the North, was struck by the combined catastrophes of bad weather, flooding, famine, and plague. This agrarian crisis crippled lowland farms more than upland pastures, but it was a difficult and discouraging setback for all the North, and its effects were felt for decades. ${ }^{20}$

The emigrant Scots captured by the 1440 tax were, then, looking for work among people who were themselves suffering new and worrying economic losses. They also encountered hostility directed towards them as Scots. National distinctions might have mattered more in Westminster and Edinburgh than along the borders, especially so in the mid-fifteenth century when the court of the march's jurisdiction over crossborder law and custom waxed in power. ${ }^{21}$ But that court spent much of its time distinguishing Scot and English, enshrining the very differences it sought to balance. And however much people in the borders shared in terms of economy, culture, and custom, they also shared a bitter history of cross-border war and raiding. Many northern English—not all, but more than enough to cause alarm for Scottish migrants and emigrants - nourished anxious memories of devastating Scottish incursions. Their dislike of Scots could be very real and personal. Scots were sometimes denied membership in English guilds and full civic status (or freedom) in English towns, and "Scot" was an easy-to-hand insult, sometimes on its own but also as an emphatic add-on to a string of other abuses-so that, for example, a person might be defamed as a "common fornicator, thief and a Scot" or as a "Scottish priest's whore." 22 Whether migrant or immigrant, a Scot in England was wise to proceed

(Philadelphia, 1982), 193-217. G. W. S. Barrow comments on military routes in his Scotland and Its Neighbours (London, 1992), 204.

${ }^{19}$ For the rural economy, see especially J. A. Tuck, "The Northern Borders," in The Agrarian History of England and Wales, vol. 3, 1348-1500, ed. Edward Miller (Cambridge, 1991), 175-82 and 587-95. For the effects of war, see J. A. Tuck, "War and Society in the Medieval North," Northern History 21, no. 1 (November 1985): 33-52.

${ }^{20}$ A. J. Pollard, "The North-Eastern Economy and the Agrarian Crisis of 1438-40," Northern History 25, no. 1 (June 1989): 88-105; John Hatcher, "The Great Slump of the Mid-Fifteenth Century," in Progress and Problems in Medieval England: Essays in Honour of Edward Miller, ed. Richard Britnell and John Hatcher (Cambridge, 1996), 237-72. Recent research particularly stresses the role of climate in this crisis: see C. Camenisch et al., "The 1430s: A Cold Period of Extraordinary Climate Variability during the Early Spörer Minimum with Social and Economic Impacts in North-Western and Central Europe," Climate of the Past 12, no. 11 (December 2016): 2107-26, http://www.clim-past.net/12/2107/2016, accessed 15 December 2016.

${ }^{21}$ Neville, Violence, Custom and Law.

${ }^{22}$ For these examples, see L. R. Poos, "Sex, Lies, and the Church Courts of Pre-Reformation England," Journal of Interdisciplinary History 25, no. 4 (Spring 1995): 585-607, at 591 (emphasis mine). Animosity towards Scots was firmly fixed in northern English culture. See especially Cynthia Neville, "Local Sentiment and the 'National' Enemy in Northern England in the Later Middle Ages," Journal of British 
with caution, expecting to be sometimes warmly welcomed and sometimes rudely rebuffed.

We do not know when the Scots tabulated in the 1440 tax arrived in England's northernmost counties or how long they stayed. We also have no direct information about why they emigrated. But we do know that emigration was common in fifteenth-century Scotland, when the realm was providing Europe with, as David Ditchburn has put it, "a swarm of itinerant Scots from Cumberland to Konigsberg." Most Scottish emigrants were skilled (priests, tailors, students, soldiers, and merchants); most were men; and many traveled much farther than merely into the English border counties, moving especially to Ireland and the south Baltic but also to the Low Countries and France. The low social profile of Scots recorded in northern England in 1440 presents a strong contrast with all these other Scottish emigrants. Even among Scots who emigrated to England in the later Middle Ages, those of 1440 were strikingly poor and unskilled. By the later fifteenth century, more and more Scottish immigrants to England were, according to James Galloway and Ian Murray, educated, skilled, urban-born, and male. ${ }^{23}$

The lowly status of Scottish emigrants in 1440 is partly an illusion, created by different sources; by the late fifteenth century, Scots in England are known to us mostly from letters of denization, an expensive option available to only a privileged few. Yet even so, Scots in 1440 were a genuinely modest group, simply because many of them were more migrants than emigrants. Mobility of labor was common enough within late medieval Scotland, and Scots might have been encouraged to venture across the border by agrarian crises (especially a poor harvest in the Borders in 1435), evictions generated by feuing (a new rental system that demanded large, up-front payments), unemployment, or even by despair over incessant local conflicts and raids. They might have been attracted to England by higher wages, more available work, and a favorable rate for changing English-earned wages into Scottish shillings and pence. Some might have emigrated to join kin, either following Scottish relatives in chain migration or connecting with English aunts, uncles, and cousins created by cross-border marriages. Ditchburn has argued that most emigrants came from eastern Scotland, especially Fife and the Borders, but also as far north as Aberdeen. ${ }^{24}$ Probably so, but the maps provided here suggest a strong secondary flow of emigration in the west. Scots traveled to England by land (using the major roads) and sea (conveyed by fishing and maritime trade). Most were recorded by tax collectors as working on small farms, perhaps because most Scots stayed in the countryside (as

\footnotetext{
Studies 35, no. 4 (October 1996): 419-37; A. King, "Englishmen, Scots and Marchers: National and Local Identities in Thomas Gray's Scalacronica," Northern History 36, no. 2 (September 2000): 217-31; Alastair MacDonald, "John Hardyng, Northumbrian Identity and the Scots," in North-East England in the Later Middle Ages, ed. Christian D. Liddy and R. H. Britnell (Woodbridge, 2005), 29-43. Yet English animosity can be over-stressed, and as Ditchburn has emphasized, many English demonstrated a "wary acceptance of the migrant Scot" ("Anglo-Scottish Relations," 334).

${ }^{23}$ James A. Galloway and Ian Murray, "Scottish Migration to England, 1400-1560," Scottish Geographical Magazine 112, no. 1 (March 1996): 29-38; J. A. F. Thomson, "Scots in England in the Fifteenth Century," Scottish Historical Review 79, no. 207 (April 2000): 1-16; David Ditchburn, Scotland and Europe: The Medieval Kingdom and its Contacts with Christendom, c. 1215-1545 (East Linton, 2001), esp. 197-265, at 216; David Ditchburn, "Anglo-Scottish Relations"; Rees Jones, "Scots in the North."

${ }^{24}$ Ditchburn, "Anglo-Scottish Relations," 324; he comments on motives for migration at 330-31.
} 
Ditchburn has suggested) or perhaps because urban-settled, wealthier Scots managed to evade the tax (as surmised by Rees Jones). ${ }^{25}$ Almost all were poor and unskilled: Rees Jones has noted the striking preponderance of servants among immigrant Scots-78 percent of Scots as opposed to 28 percent of all aliens in the realm. ${ }^{26}$

Whatever propelled them across the border, many Scots continued to move within England. In Cumberland and Westmorland, almost three-quarters of Scots (see table 3 below) were reported to have moved between assessment for the tax (in July or August) and its collection (September-November). Some of these movements were likely fictional excuses for uncollected tax, but there can be little doubt that many Scots in England were willing and able to move on. Yet, aside from a few individuals identified as "vagabonds" (discussed more fully below), most were surely not, as has sometimes been assumed, transient harvest workers who stayed only a few days in one place. ${ }^{27}$ Why would busy constables have bothered to record harvest workers as liable for the tax? Harvest crews were usually beneath notice-too poor to pay the tax and unlikely, in any case, to still be around months later when tax collectors arrived. Instead of searching out such marginal folk, the constables focused on Scots in secure employment; in Cumberland and Westmorland, for example, nine of every ten non-householders identified for the tax were servants, settled in steady, contracted employment. A handful of laborers, common servants, and tradesmen were also noted in the tax, but they were relatively few, and many of these also seem firmly settled. To put it another way, the Scots recorded in the 1440 tax were mobile, but they were not always on the move. We might call some "migrants" because they eventually moved back across the relatively porous Anglo-Scottish economic border, and we might call others "emigrants" because, having crossed the border, they remained. But these are distinctions that might have mattered little to a Joan Scot or a John Scot-and the many other hundreds like them-recorded by English officers in 1440. These women and men had simply moved because they were looking for work; they had settled for a time where good work could be found; and they were ready to move again when needed, to find further work.

\section{GENDER, HOUSEHOLD, AND SETTLEMENT}

The experiences of Scots in England were, of course, highly varied. Some were wealthier than others, some younger or older, some skilled and some not. Some found steady work, but others did not. And although some were stung by English hostility towards Scots, others found more acceptance and even friendship. Although we can only guess about such experiences, the alien subsidy allows us to examine three distinctions in detail: the gender of Scottish aliens, their household status, and where they were to be found in the summer of 1440 .

Householders, who accounted for roughly a quarter of Scots in the North, headed critical units in English law, custom, and society, and they were usually self-supporting, self-housed, and domestically authoritative. We can roughly expect that most

${ }^{25}$ Ibid.; Rees Jones, "Scots in the North."

${ }^{26}$ Rees Jones, "Scots in the North."

27 See, for example, Ditchburn, "Anglo-Scottish Relations," 329. 
householders were married, remarried (men only), or widowed (most women, some men), but marriage did not necessarily make a householder: some married taxpayers were categorized as non-householders, and at least two female householders might have never married. ${ }^{28}$ In determining householder status, authority over household dependents was perhaps as important as marriage, and separate lodging mattered too. A married couple who lived in an employer's household could be reasonably categorized as non-householders. And a not-married person who lived alone could be fairly judged the head of a household of one. In any case, these were exceptions. Most Scottish householders in the northern borders were married men or widows, and because most female-headed households were created by the accident of male death, gender differences among Scots householders were correspondingly muted.

To judge from what the tax tells us, Scottish householders-male as well as female-were not a distinguished group. Householders were fewer than was common among aliens elsewhere (27 percent, as opposed to 38 percent realmwide); only a handful, mostly in towns, were identified with occupations, all modest (tailors, shoemakers, carters, and the like); very few took in Scottish servants, possibly because they were too poor to employ any servants at all; and strikingly more Scottish householders were women than was usual among aliens elsewhere (14 percent, as opposed to 4 percent realm-wide). Perhaps, compared to widows of other nationalities, more Scottish widows emigrated; or perhaps Scottish wives who lost their husbands while in England were less likely to repatriate.

But no matter how modest their skills and resources, Scottish households tended to settle in England in distinctive ways, almost as if they knew exactly where best to relocate (see map 2). ${ }^{29}$ And perhaps they did, for the returns suggest-in sequential listings of male householders who shared a surname-that brothers or cousins sometimes moved their families together or settled one after the other, in chain migration. For example, constables in Cumberland noted Robert and William Pule in Holme, Herbert and John Thomson in Burgh by Sands, Robert and Thomas Wylde in Cardurnock, Walter and John Broune in Great Corby, and Richard and John Blyth in Brampton.

In Cumberland, Scottish households congregated close to the border, most either in Carlisle itself or in wings spreading west or east from the town. To the west (towards Bowness-on-Solway and then down the coast as far as the modern town of Maryport), male householders predominated among Scots settlers. Some of these men and their families probably traveled by sea and settled close to their points of arrival. But others likely came overland to an area that offered them good livings in the local fishing and salt-making industries. At Holme (modernday Abbeytown), twelve male householders were recorded, along with only six non-householders (three males and three females). Holm Cultram Abbey was a daughter house of Melrose, founded in the mid-twelfth century when the area was

\footnotetext{
${ }^{28}$ These non-householding males in Northumberland had wives who were named but not taxed: EIDB\#7654/7655; 7054/7055; 6458/6459; 7335/7336; and 6969/6972. Also, two married couples in Cumberland worked as servants (and both husband and wife were taxed): EIDB\#29702/29704 and 29733/29734. The two unmarried female householders-Alice Atkynson of Newcastle, EIDB\#8713, and Margaret Kapnytter of Ponteland, EIDB\#6713 - are considered more fully below.

${ }^{29}$ A few dozen individuals in tables 1 and 2 are not included in the maps as their locations could not be determined.
} 


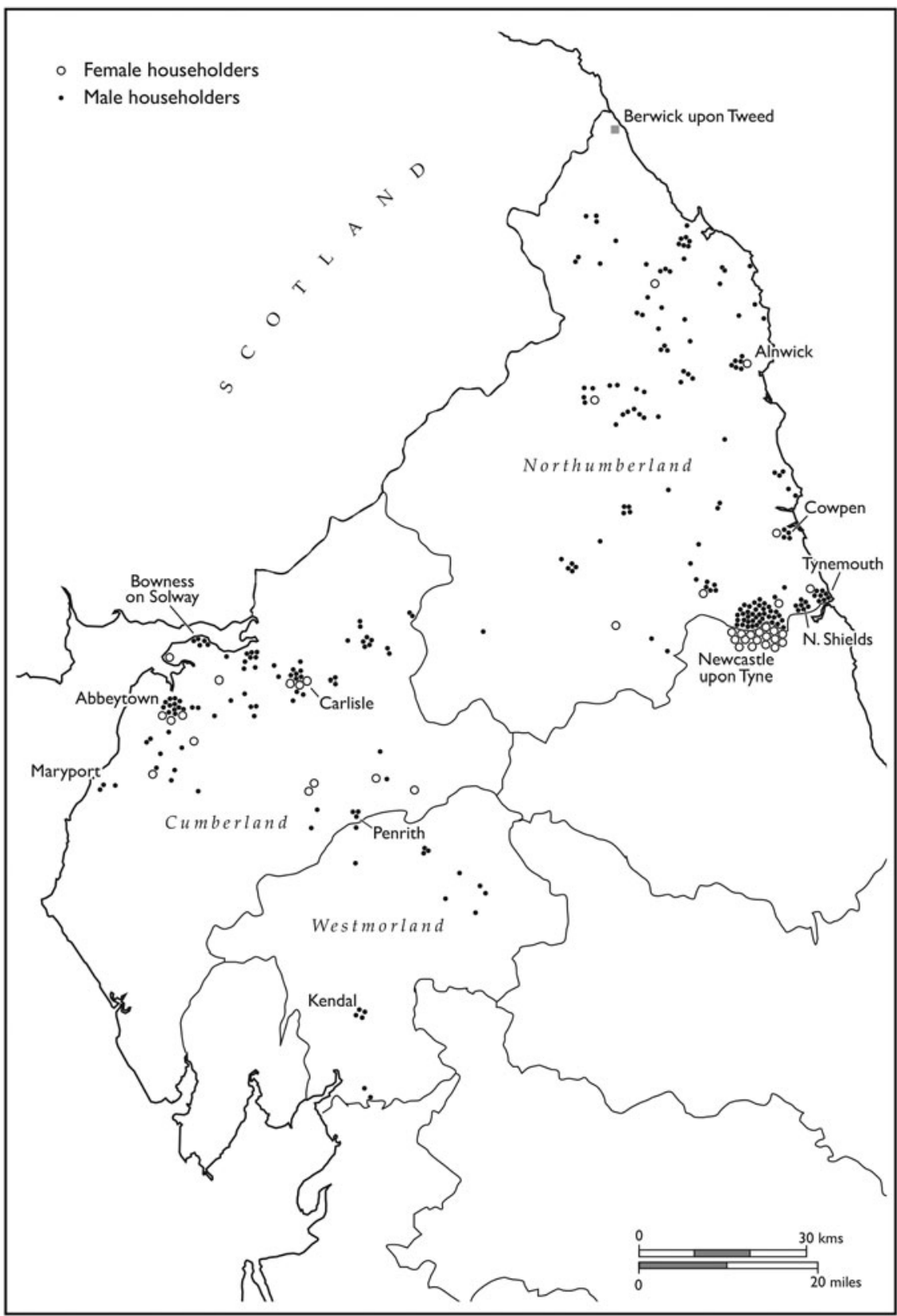

Map 2-Scottish Householders in the North of England, 1440. 
in Scottish hands, and it was supervised by its Scottish mother house through the fifteenth century; perhaps these ties especially attracted Scottish emigrants to the abbey and its town. ${ }^{30}$ To the east (roughly along the ancient route of Hadrian's Wall), Scots found employment-and possibly land to farm - in the Irthing valley. Very few householders headed due south of Carlisle, and even fewer traveled as far south as Westmorland. These settlement patterns are particularly marked for male householders. In both Cumberland and Westmorland, female householders were few and dispersed; most were surely widows who had emigrated with husbands who subsequently died.

In Northumberland, Scottish households might also have clustered just south of the border, but if so, we cannot see them, because aliens in the Durham-held liberties below Berwick were not taxed. It is clear, however, that Scottish immigrants in Northumberland moved much more resolutely southward than did those in the northwest. Fully two-thirds of female householders (seventeen) settled in Newcastle, and about a quarter of male householders established themselves in Newcastle (fortytwo) or North Shields and Tynemouth (fifteen). The draw of Tyneside looks almost magnetic on the map, pulling Scottish households down to the opportunities of trade, shipping, mining, fishing, and salt-making along the river and its estuary. ${ }^{31}$

Non-householders were, in theory, everyone who was not a householder, and they are key to the puzzle of why women were so abundant among Scots reported in the northern borders. As table 1 shows, women were strikingly present in this group: they outnumbered non-householding men in Cumberland and Westmorland; they accounted for about one-third of non-householders in Northumberland; and perhaps most tellingly, they constituted the vast majority of taxed women in all three counties. In compiling lists of non-householders, constables and justices of the peace usually ignored wives and children (even those older than twelve) in alien homes and focused instead on alien servants and laborers, most of them employed in English homes. The equivalence of these workers with "non-householder" is unusually explicit in the northern returns. In Cumberland, the list for non-householders was initially titled "Names of Servants in Cumberland who are not English-born" (another clerk later added the technical specification "non-householders”). In Northumberland, clerks occasionally bracketed groups of non-householders as "servants and vagabonds" or "laborers and vagabonds." 32

A few of these non-householding servants, laborers, and vagabonds were married people. Seven married couples were explicitly noted; a few more can be discerned from incidental references; and a handful of others might linger unidentified among male-female dyads employed in the same household (ten in Cumberland, three in Westmoreland, four in Northumberland). In later centuries, the employment of married couples as farm servants, although never the norm, was especially common in lowland Scotland and northern England, where a male laborer or

\footnotetext{
${ }^{30}$ For Melrose Abbey's continued authority over the monks of Holm Cultram, see Keith Stringer, "Identities in Thirteenth-Century England: Frontier Society in the Far North," in Social and Political Identities in Western History, ed. Claus Bjorn, Alexander Grant, and Keith Stringer (Copenhagen, 1994), 28-66, at 58 .

${ }^{31}$ Rees Jones, "Scots in the North," traces how maritime trading and fishing influenced Scots migration as far south as Yorkshire.

${ }^{32}$ TNA, E179/90/27 and E179/158/41.
} 
plowman (a "hind") was employed on the condition that he also supply his wife's labor. Perhaps this practice was already beginning in 1440. But some of these male-female dyads might reflect another variation in the employment of hinds; if not married, a hind was obliged to bring with him a female laborer (or "bondager") who was often unrelated to him. ${ }^{33}$ In any case, most of the women and men categorized in the tax as "non-householders" were listed on their own account, entirely unattached to anyone except a master or mistress. Their single status is particularly clear for women, as most widows would have been categorized in the 1440 tax as householders, and most wives were not listed at all. Because men's marital status was rarely reported, it is possible that a few seemingly single males among nonhouseholders were, in fact, married. In short, although perhaps a dozen or so married men and women are hidden in listings of "non-householders," the vast majority of the 784 individuals in this category were singletons, most of them never married. At least two additional singletons can be found among householders: Alice Atkynson of Newcastle, noted as the daughter of another householder, and somewhat more tentatively, Margaret Kapnytter of Ponteland, whose constable was tellingly confused as to whether she qualified as a householder or a non-householder. As shown in table 2, the resulting numbers of presumed singletons differ only slightly from counts of non-householders in table 1 .

The tax returns offer no data on ages, but most singletons were likely in their later teens or twenties, working to gain skills and resources before they married. Some people, of course, married late or never married, so that some servants (and some laborers, too) aged in the role. Because the single immigrants we can see in 1440 had left behind in Scotland many of the usual buttresses for marriage-making (especially parents, friends, and neighbors), they were especially vulnerable to delayed marriages or non-marriage. But most of these Scottish singletons were youngsay, somewhere between fifteen and thirty years of age-and not yet married.

Although these young men and women were on their own in England, they were not always alone. Some migrated with family or friends, and some were surely chain migrants, following after others who had gone before. In Cumberland, for example, Matthew Lidale and his sister Margaret both found employment with Alan Robson of Walton; John Scot, William Pierson, and Thomas Raa worked for John Denton of Ainstable; and Joan Scot and Margaret Scot served Emmota widow of John Brown of Carleton. About one in five servants found employment in pairs or sometimes threesomes; this was as true for women as for men, and the groupings were as likely to be single-sex as to include both sexes. But most singletons were not so lucky, and they lived, as best we can tell, without the company of siblings, companions, or friends. Although some lodged deferentially in employers' households,

\footnotetext{
${ }^{33}$ For the employment of male hinds with attached female laborers (wives, daughters, or bondagers) in northern Britain, see T. M. Devine, Farm Servants and Labour in Lowland Scotland, 1770-1914 (Edinburgh, 1984), esp. 81-83 and 156-63, and Valerie G. Hall, Women at Work, 1860-1939: How Different Industries Shaped Women's Experiences (Woodbridge, 2013), 124-30. I am grateful to Keith Wrightson for alerting me to these distinctive practices of rural service in northern Britain. See also Dinah Iredale, Bondagers (Wooler, 2008). In the 1440 returns, I have found only one case of a servant with a servant, and it does not conform to the hind/bondager model: George Collier, servant of Robert of Mitford) (EIDB\#6468) and his servant William (EIDB\#6473). TNA, E179/158/41, m. 4. This relationship is not noted in the EIDB.
} 
Table 2-Singleton Scots in the English North in 1440.

\begin{tabular}{lcccc}
\hline & Cumberland & Westmorland & Northumberland & Totals \\
\hline Male singletons & 96 & 39 & 310 & $\mathbf{4 4 5}$ \\
Female singletons & 121 & 47 & 161 & $\mathbf{3 2 9}$ \\
Totals & $\mathbf{2 1 7}$ & $\mathbf{8 6}$ & $\mathbf{4 7 1}$ & $\mathbf{7 7 4}$ \\
\hline
\end{tabular}

others lived apart in lodgings or encampments. Because most were reported as working in villages or towns where other Scots lived, they were not entirely bereft of compatriots.

These singleton Scots scattered themselves all over the English North, but women scattered more widely than men. The tax returns offer three direct indications of the greater mobility of singlewomen. First, the term vacabondus/a was particularly associated with women. A few clerks in Northumberland used the term generally and without regard to gender, titling entire groups of non-householding aliens as "servants and vagabonds" or "laborers and vagabonds." But in Westmorland, a handful of scattered individuals were specifically identified in this way, and there, almost all vagabonds were women: specifically, eight Scotswomen and one Irishman. In late medieval English, the term "vagabonds" could denote any wanderers, or particularly dangerous and violent wanderers, or particularly poor (and begging) wanderers. $^{34}$ The frequent linkage in the Northumbrian returns of "servants and vagabonds" suggests that the two groups were viewed similarly, and this makes good sense-like vagabonds, servants moved in search of work, and like servants, vagabonds tarried wherever employment was to be had. ${ }^{35}$ And since each of the eight Scotswomen identified as vacabunda was deemed taxable, they clearly were not beggars. More than likely, these vagabonds moved more often than most other servants and workers, possibly working the harvest as it moved north or otherwise following itinerant employment opportunities. If so, the fact that only these few itinerant workers were singled out for notice is yet another quirk of the taxation process, but the predominance of women in the category nevertheless stands out.

Second, since the parliamentary grant had provided that sheriffs would not be liable for aliens who moved in the interval between assessment and collection, the

\footnotetext{
${ }^{34}$ For the general use of the term, see s.v., "vagabundus," Dictionary of Medieval Latin from English Sources, http://logeion.uchicago.edu/index.html\#vagabundus, accessed 10 April 2017; for associations with violence, especially the violence of unemployed soldiers, see Richard W. Kaeuper, War, Justice, and Public Order: England and France in the Later Middle Ages (Oxford, 1988), 172-73; for associations with poverty and begging, see Marjorie McIntosh, Controlling Misbehavior in England, 1370-1600 (Cambridge, 1998), 89-93. In the Middle Ages, wandering had positive as well as negative connotations; it was associated with saints, friars, students, and pilgrims, as well as beggars and thieves.

${ }^{35}$ Ditchburn, "Anglo-Scottish Relations," 329, gives a particularly telling instance of the merging of laborers, servants, and vagabonds. Chris Given-Wilson has noted that in 1446 justices of the peace were empowered to reassign idle servants, "treating them in every respect just as they treated vagabonds": Chris Given-Wilson, "Service, Serfdom and English Labour Legislation, 1350-1500," in Concepts and Patterns of Service in the Later Middle Ages, ed. Anne Curry and Elizabeth Matthew (Woodbridge, 2000), 21-37, at 29. For the later convergence of vagrant and migrant, see David Hitchcock, "A Typology of Travellers: Migration, Justice, and Vagrancy in Warwickshire, 1670-1730," Rural History 23, no. 1 (March 2012): 21-39.
} 
Table 3-Scots in Cumberland and Westmorland Who Moved between Assessment and Collection.

\begin{tabular}{lccc}
\hline Taxpayer type & $\begin{array}{c}\text { Individuals } \\
\text { Assessed }\end{array}$ & $\begin{array}{l}\text { Individuals Moving } \\
\text { before Collection }\end{array}$ & $\begin{array}{c}\text { Proportion } \\
\text { Who Moved }\end{array}$ \\
\hline Male householders & 95 & 61 & $64 \%$ \\
Male singletons & 135 & 88 & $65 \%$ \\
Female householders & 14 & 14 & $100 \%$ \\
Female singletons & 168 & 136 & $81 \%$ \\
Totals & 412 & 299 & $73 \%$ \\
\hline
\end{tabular}

sheriffs' returns sometimes note these movements. The data are especially robust for Cumberland (movement between August and November) and Westmorland (movement between July and September). As shown in table 3, the returns identified many more women than men as moving between assessment for the tax and its collection few months later.

Although the numbers are small, it is striking that every female householder moved, and their mobility perhaps speaks to the particular vulnerability of emigrant widows. The fuller numbers for the movement of single folk-both male and female-provide a more reliable and telling contrast: roughly, two out of every three bachelors and four out of every five singlewomen. Although we lack information on movement for most taxpayers in Northumberland, the data there also show a gender divide: 42 percent of female singletons moved before collection (67 of 161), as opposed to 35 percent of male singletons (107 of 308). ${ }^{36}$ Some of these "movements" were surely documentary fictions, convenient excuses for payments uncollected because taxpayers were poor or officials lazy. But the gender differences here are too striking to dismiss as entirely bureaucratic creations.

Third (and most compellingly), when the tax homes of Scots are plotted on maps, distinct gender patterns emerge (see maps 3 and 4). In Northumberland, most single men (two-thirds) moved no farther south than Alnwick. They settled along the northern coast where fishing was likely a major employment; in the stock-raising foothills of the northern Cheviots; and in Alnwick, a center of Percy military power. Singlewomen had to travel farther to find work, only half of them settling in or north of Alnwick, and a full quarter moving as far south as Newcastle, a town that attracted many more singlewomen (thirty-five) than single men (thirteen). Also, fewer women than men found work on or near the two major North-South routes in the county (today's Al and A697). In Cumberland and Westmorland, the patterns are much the same. Carlisle attracted fewer singletons, but (again) twice as many women (ten) as men (four). Single Scots of both genders found employment primarily on farms in the Eden valley, although men (again) found rather more work in the foothills. And women (again) traveled farther than men; 53 singlewomen settled south of Penrith, as compared to only $38 \mathrm{men}$, and only one man (but seven women) made it to Kendal or beyond.

\footnotetext{
${ }^{36}$ The total here is 308 instead of 310 because two male singletons were reported as dead by the time of collection.
} 


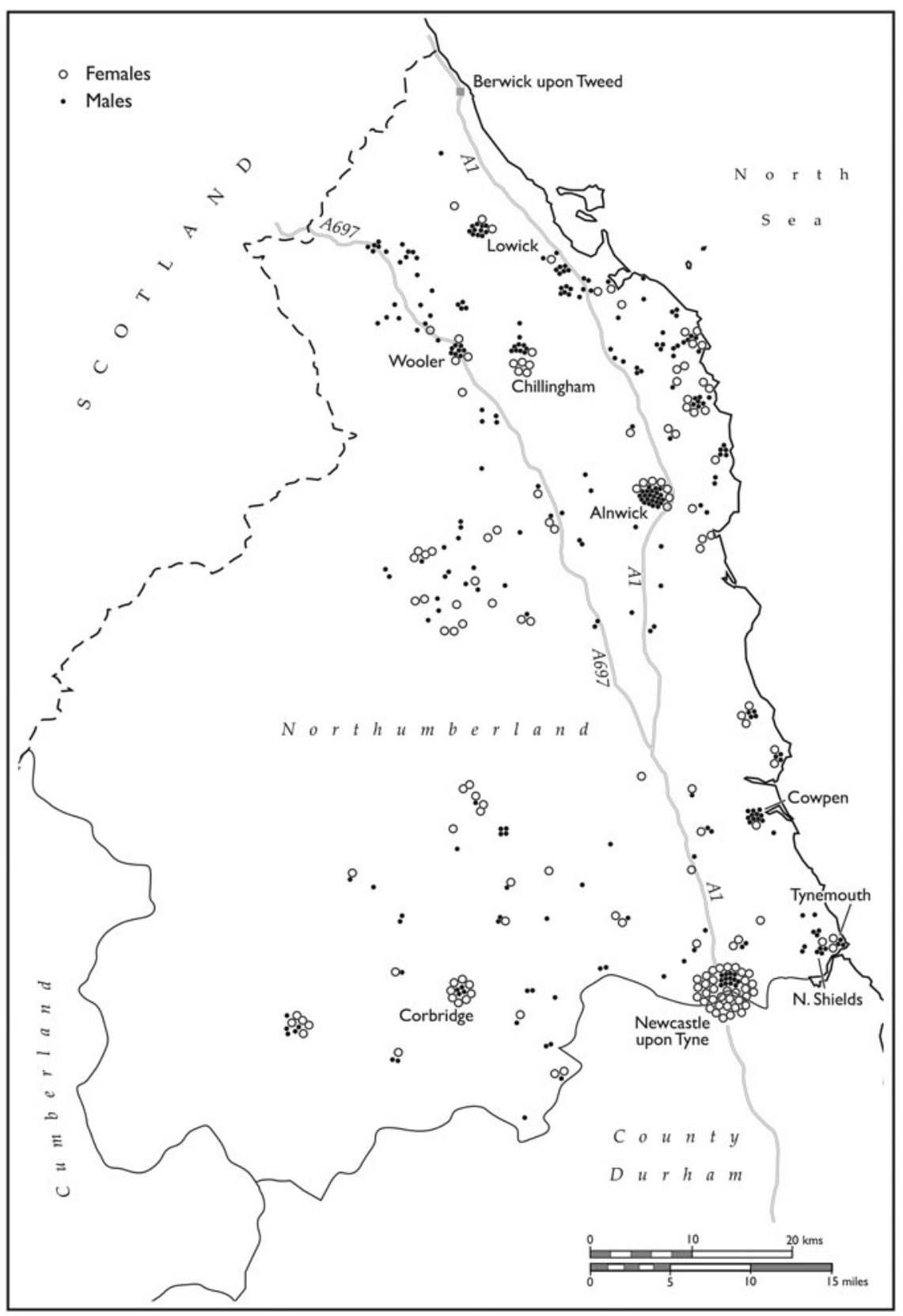

Map 3-Scottish Singletons in Northumberland, 1440. 


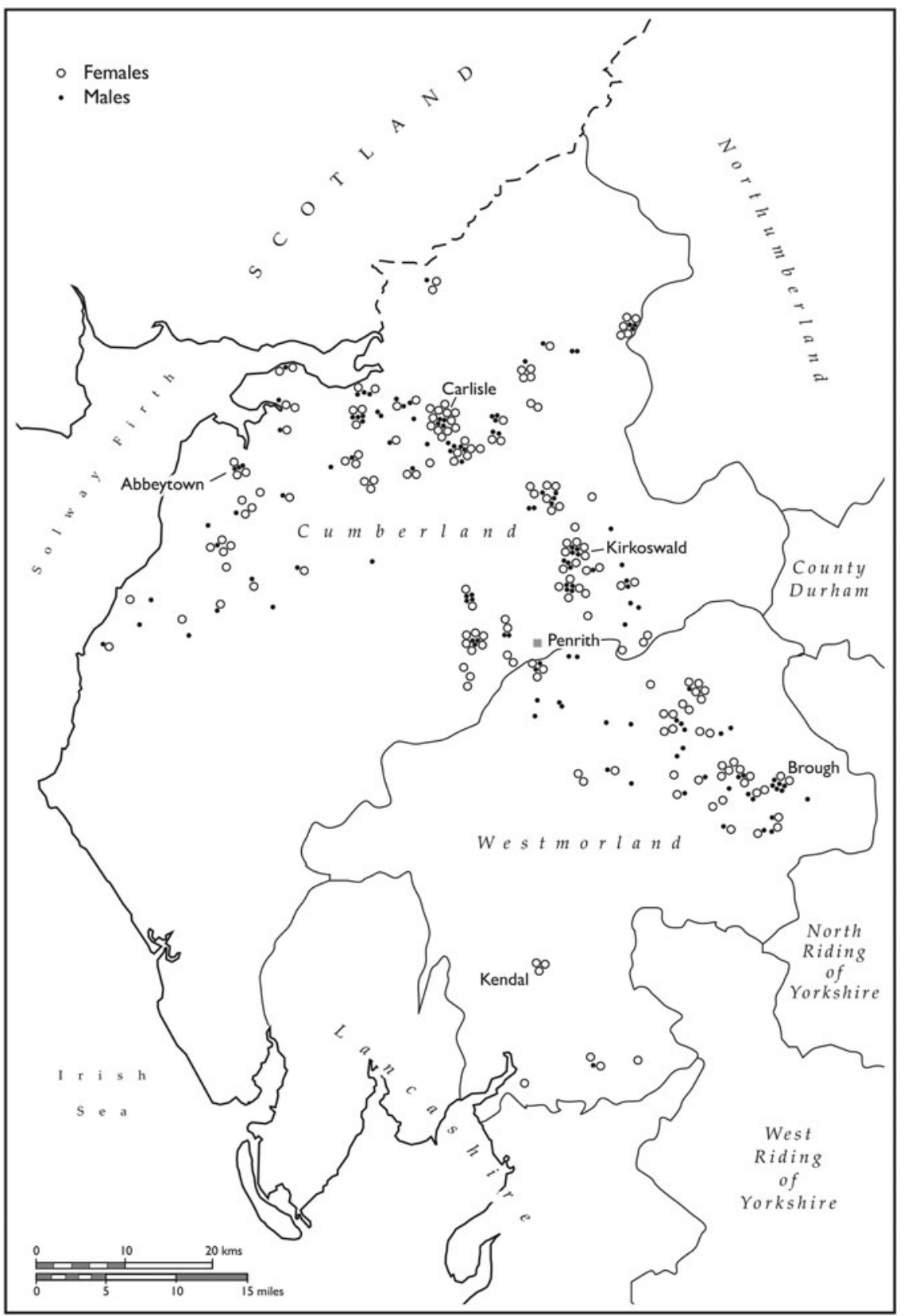

Map 4-Scottish Singletons in Cumberland and Westmorland, 1440. 
These Scottish women who were on their own traveled farther than did men, even though their travel was harder. Because women were unwelcome aboard ships and boats, the Scottish singlewomen we can locate in places like Newcastle and Kendal were unlikely to have worked their way south by getting short-term employment on coastal ships or fishing boats-or even, if they could afford it, by paying a fare. Instead, they traveled by land, walking to Newcastle or Kendal, or catching rides. Roads had their own particular challenges for women-risk of rape and theft, as well as the constant worry that shelter or food would be obtained only in return for sexual favors. Given the difficulties of movement by both land and sea, it is unlikely that singlewomen were footloose by choice. Women moved more because they had to look harder for employment-pushing farther into England, walking farther off the main roads, and ending up more often in English towns.

Women also seem to have known where best to look for suitable work. In Northumberland in particular, singlewomen seldom clustered in the towns that attracted many single Scotsmen-such as Alnwick, Wooler, Chillingham, Cowpen, Tynemouth, and North Shields. Presumably, they knew that these places offered work for cattlemen, fisherman, miners, and soldiers, but not much work for women. ${ }^{37}$ So singlewomen took themselves elsewhere, many to Newcastle where almost all worked as servants. With a steady trade in wool, hides, and coal, Newcastle was one of England's largest towns, a strong rival to York's claim to be the urban center of the North. ${ }^{38}$ Scotswomen settled in Newcastle in exceptional numbers. Women constituted only a quarter of immigrants in such southern English cities as London and Bristol, but in Newcastle (and Carlisle, too) women actually outnumbered men among Scottish immigrants. Newcastle boasted one of the two singlewoman-householders identified in the 1440 tax (Alice Atkynson), and since the town attracted far more than its fair share of female householders, perhaps Atkynson was just one of several singlewomen who established households in the town. Most other female householders were surely widows-either "made-in-Newcastle" widows or widows who chose to move their households to the town. In their enthusiasm for urban life, Scotswomen look less like immigrant women from other realms and more like Englishwomen; they were best able to move by foot and road, and they often turned their feet towards towns-whether for better or worse, whether in final desperation or eager hope.

Tax officers were not required to provide occupations, but their returns nevertheless clearly indicate that all but a few singleton Scots worked in service. Only a few (all men) were identified by other occupations: nine were chaplains, but there were also three shepherds, two miners, two salters, a skinner, and a vicar (in Wooler). In Northumberland, some others might have supported themselves by wage-labor, as they were identified as "laborers" (fourteen, of whom two were women) or as generic "servants" with no employers noted (nineteen, of whom four were women). In

\footnotetext{
${ }^{37}$ For Scots as soldiers in English armies, see Adrian R. Bell et al., The Soldier in Later Medieval England (Oxford, 2013), 242-43.

${ }^{38}$ Jennifer Kermode, "Northern Towns," in The Cambridge Urban History of Britain, vol. 1, 600-1540, ed. D. M. Palliser (Cambridge, 2000), 657-80, and in the same volume, Alan Dyer, "Appendix: Ranking Lists of English Medieval Towns," 747-70. For a summation of Newcastle's medieval economy, see Constance M. Fraser, "The Economic Growth of Newcastle, 1150-1536," in Newcastle and Gateshead before 1700, ed. Diana Newton and A. J. Pollard (Chichester, 2009), 41-65.
} 
Cumberland, seven women and eight men identified as common servants might have similarly labored for multiple employers and possibly for day wages. All these were exceptions: most Scots in 1440 were settled into contracted service with a master, a mistress, or, in a few cases, an ecclesiastical establishment. In the two western counties, almost all singletons were identified as servants of specific masters or mistresses (75 of 86 in Westmoreland; 195 of 217 in Cumberland). In Northumberland, servants attached to specific households predominated in jurisdictions that commented on employment (123 of 169), but many jurisdictions offered little or no occupational information; given known proportions elsewhere, it is reasonable to surmise that most of the 301 singletons in these districts must have also been servants. To judge by the better data for the two western counties, about nine of every ten singlewomen and bachelors supported themselves in this way.

Servants usually contracted for set terms-quarter, half, or full year-changing employments in early summer (at Whitsun) and autumn (at Michaelmas or Martinmas). Almost all worked for English employers, bending themselves to domestic authority and agreeing to work as required. In return, English masters and mistresses offered remuneration, usually some combination of during-the-term support (shelter and food) and end-of-term reward (in cash or goods). They also offered some measure of social protection, especially for servants accommodated within the household. Usually hired as general workers, servants undertook, as Robert Loder straightforwardly put it in his early seventeenth-century accounts, "the doing of the things that must indeed be done." 39 Most worked on farms or in workshops, occupied in the industrial, agricultural, and pastoral tasks of northern households. Female servants additionally helped with household work, childcare, and spinning, but these tasks were supplemental to other work. Rather more women than men found employment as servants in towns (they accounted for ten of fourteen servants in Carlisle and thirty-four of forty-six in Newcastle). Men more readily secured positions in monastic establishments (male as well as female); women had an edge when widows

\footnotetext{
${ }^{39}$ As quoted in Jane Whittle, "Housewives and Servants in Rural England, 1440-1650: Evidence of Women's Work from Probate Documents," Transactions of the Royal Historical Society, no. 15 (December 2005): 51-74, at 62. Whittle's excellent work on female servants is the best guide; see also her "Servants in Rural England c. 1450-1650: Hired Work as a Means of Accumulating Wealth and Skills before Marriage," in The Marital Economy in Scandinavia and Britain, 1400-1900, ed. Maria Ågren and Amy Louise Erickson (Aldershot, 2005), 89-110. For medieval servants in particular, see Madonna J. Hettinger, "Defining the Servant: Legal and Extra-Legal Terms of Employment in Fifteenth-Century England," in The Work of Work: Servitude, Slavery, and Labor in Medieval England, ed. Allen J. Frantzen and Douglas Moffat (Glasgow, 1994), 206-28; Ann J. Kettle, "Ruined Maids: Prostitutes and Servant Girls in Later Medieval England," in Matrons and Marginal Women in Medieval Society, ed. Robert R. Edwards and Vickie Ziegler (Woodbridge, 1995), 19-35; P. J. P. Goldberg, "What Was a Servant?," in Curry and Matthew, eds., Concepts and Patterns of Service in the Later Middle Ages, 1-20; Given-Wilson, "Service, Serfdom"; Deborah Youngs, "Servants and Labourers on a Late Medieval Demesne: The Case of Newton, Cheshire, 1498-1520," in Agricultural History Review 47, no. 2 (1999): 145-60; Kim Phillips, Medieval Maidens: Young Women and Gender in England, 1270-1540 (Manchester, 2003), 120-35; Judith M. Bennett, "Compulsory Service in Late Medieval England," Past and Present, no. 209 (November 2010): 7-51. For Scotland, medieval archives reveal little about servants, but see Elizabeth Ewan, "Mistresses of Themselves? Female Domestic Servants and By-Employments in Sixteenth-Century Scottish Towns," in Domestic Service and the Formation of European Identity: Understanding the Globalization of Domestic Work, 16th-21st Centuries, ed. Antoinette Fauve-Chamoux (Bern, 2004), 411-33.
} 
were hiring. Women also predominated among servants in the households of parish priests, and some of these likely were, as elsewhere, de facto wives. ${ }^{40}$

The national origins of these Scottish servants certainly mattered, but it is also useful to understand them as part of a labor pattern that transcended realm and nation, a pattern that is now well recognized by historians of premodern England and Scotland. In both realms, it was common for young people to leave home in search of employment, particularly employment in service. Home-leaving was not necessarily voluntary - some lucky children, particularly heirs, stayed at home until marriage, while their siblings were encouraged to leave. Home-leaving was also not necessarily permanent-some returned after only a few years; some returned to their home village but not the parental home; and others never came back at all. Most left with the hope that their time in service (or, in some cases, apprenticeship) would be temporary, merely a work-and-training stage in their transition from dependent child to married adult. They mostly set out from home, as best we can tell, in their middle to late teenage years, and if the transition worked as it ideally should, young people thereby expanded their social horizons, accumulated some capital, learned new skills, and slowly moved toward married adulthood. They also physically moved, not only out of parental households but also away from villages, and even out of regions or indeed, realms. If the Scots had taxed their aliens in 1440, we might perhaps find young Englishmen and young Englishwomen similarly laboring on Scottish farms, for the regional traffic in servants might have moved north as well as south. ${ }^{41}$

It was common among English servants for their work to differ by gender-for women to be paid much less than men, for female servants to suffer more sexual abuse, and possibly also for women more often to obtain only short-term contracts or to encounter trouble collecting remuneration at the contract's end. ${ }^{42}$ The opportunities of immigrant Scotswomen were doubtless diminished accordingly, and the constables and clerks who compiled the alien returns spoke, in their own distinctive ways, about the lesser status of female servants. They reduced many more women than men to mere forenames, identifying them without any surname at all, except the generic "Scot" (123 women, 79 men). They also found five women (but no men) to be unworthy of even a forename. ${ }^{43}$ It would be hard to argue that the

${ }^{40}$ Janelle Werner, "Living in Suspicion: Priests and Female Servants in Late Medieval England," Journal of British Studies 55, no. 4 (October 2016): 658-79.

${ }^{41}$ P. J. P. Goldberg, "Marriage, Migration and Servanthood: The York Cause Paper Evidence," in Woman Is a Worthy Wight: Women in English Society, 1200-1500, ed. P. J. P. Goldberg (Stroud, 1992), 1-15; and P. J. P. Goldberg, "Migration, Youth and Gender in Later Medieval England," in Youth in the Middle Ages, ed. P. J. P. Goldberg and Felicity Riddy (York, 2005), 85-99. For the historiography of late medieval adolescence generally, see Deborah Youngs, The Life Cycle in Western Europe, c. 1300c. 1500 (Manchester, 2006), 96-125.

${ }^{42}$ For wage differentials, see Jane Humphries and Jacob Weisdorf, "The Wages of Women in England, 1260-1850," Journal of Economic History 75, no. 2 (June 2015): 405-44; for sexual abuse, see Kettle, "Ruined Maids"; for shorter contracts, see Goldberg "What Was a Servant?," 12; Deborah Youngs, "The Townswomen of Wales: Singlewomen, Work and Service, c. 1300-c. 1550," in Urban Culture in Medieval Wales, ed. Helen Fulton (Cardiff, 2012), 163-82, at 168-69; Deborah Youngs, "Servants and Labourers on a Late Medieval Demesne," 149. For difficulties collecting wages, see Henry Summerson, Medieval Carlisle: The City and the Borders from the Late Eleventh to the Mid-Sixteenth Century, vol. 2 (Kendal, 1993), 684.

${ }^{43}$ EIDB\#29876; 29877; 29878; 29565; 29566. 
clerk who compiled the 1440 return for Cumberland thought that Robert Bate of Glassonby employed three Scottish servants of equal value. He listed the first servant, Thomas Scot, on his own and then separately noted that the household also contained two Scottish ancille whose names were unknown to him. Ancilla is commonly translated today as "maidservant," a meaning especially suited for devout women who, emulating Mary at the Annunciation, sought to be an ancilla Dei. ${ }^{44}$ But "maidservant" obscures the word's strong connotations in lay contexts of subjection and even bondage. In the late medieval Mediterranean, as Sue Stuard has shown, an ancilla was simply a female slave. ${ }^{45}$ In late medieval England, where chattel slavery was much less common, the word retained its strong connotation of subservience. ${ }^{46}$ As John Trevisa put it in his late fourteenth-century English translation of the compendium De Proprietatibus Rerum, an ancilla was "held low under the yoke of thralldom and servitude."47

\section{CONCLUSIONS}

I have finished this project as a grateful but cautious user of the EIDB. By 2005, my archival work had confirmed that unusual numbers of single Scotswomen lived in the English North at the time of the first alien tax, but I shied away from the extensive labor needed to contextualize this finding. When the EIDB was fully launched in 2015 , it provided instant solutions to these challenges, allowing me, for example, to establish a national view of gender ratios (map 1) and to ascertain the locations of individual Scots (maps 2-4). ${ }^{48}$ A model of a user-friendly and accessible database, the EIDB was created by historians and for historians, and judged by the terms set out in Tim Hitchcock's recent critique of digital resources, it is as good as it gets. ${ }^{49}$ It is, of course, not perfect, but it is both accessible and authoritative, and for most students of the alien subsidies, will largely replace the original documents. It is thus both a friend to historians (giving us ready access to large amounts of data) and our foe (pulling us away from our original sources).

Digital databases are new, but historians, particularly historians of medieval and early modern societies, are familiar with the genre; a database like the EIDB is not so very different from a modern print edition of a premodern text. Both require extensive editorial decisions; both make inaccessible information more accessible; both can trip the unwary. How, then, might we best work with old sources newly

\footnotetext{
${ }^{44}$ Goldberg argues that the term evokes youth, devotion, innocence, virginity, and even personal service to a mistress. Goldberg, "What Is a Servant?," 1-7.

${ }^{45}$ Susan Mosher Stuard, "Ancillary Evidence on the Decline of Medieval Slavery," Past and Present, no. 49 (November 1995): 3-32.

${ }^{46}$ Hettinger, "Defining the Servant," 218-19.

${ }^{47}$ EIDB\#29564-6; M. C. Seymour, ed., On the Properties of Things, John Trevisa's Translation of Bartholomaeus Anglicus, De Proprietatibus Rerum, vol. 1 (Oxford, 1975), 305-6, book 6, capt 11: De Ancilla. The entry is long and revealing.

${ }^{48}$ I found the EIDB maps difficult to maneuver, and because coordinates were not provided for place names, it was not possible to move the data into other mapping formats. I remapped locations on my own (using postcodes and Google Maps). Even so, the EIDB saved me the labor of matching medieval place names to modern places.

${ }^{49}$ Tim Hitchcock, "Confronting the Digital: Or How Academic History Writing Lost the Plot," Cultural and Social History 10, no. 1 (March 2013): 9-23.
} 
clothed in digital trappings? First, just as we check editions on critical points, we must do the same with databases. In my case, I eventually checked every entry in my threecounty EIDB dataset against the original returns of the 1440 tax to be sure that attributions of gender and tax status were accurate. I found a few errors and adjusted my figures accordingly. ${ }^{50}$ This is not reinventing the wheel; it is ensuring that the wheel runs true. Digital databases are not yet, as a matter of course, subjected to the systematic evaluation of peers that we can expect of any book or printed edition-that is, neither reviewed by anonymous readers pre-launch nor reviewed for the public thereafter. We have every reason to believe that database editors do their very best to be accurate, but in the absence of established review policies, we really have no choice but to check for ourselves. Second, users must be highly alert to the myriad ways that editorial decisions about databases-essentially, decisions about how to wrangle messy text into neat spreadsheets-reshape original sources much more profoundly than any textual edition. Even the EIDB, which richly provides user-friendly background, offers up some rude shocks for its users. For example, the downloaded spreadsheets are not as exhaustive as they seem, for information on relationships between persons are included in online entries but omitted in downloads. A good rule is to approach a database like any other edited source, asking at the outset who edited it, when, why, and for what purposes, and then playing with the database a good deal before settling into systematic work. Finally, and at risk of stating the obvious, anyone who uses a database like the EIDB must keep close to the original documents throughout. Even the most accurate information in a database cannot always convey the power of its original. It was one thing for me to read in the EIDB that the householder Margaret Kapnytter of Ponteland was "also entered erroneously amongst the non-householders and subsequently crossed out." ${ }^{11}$ But it was not until I reread the document-and saw Margaret listed once with the householders and again with the non-householders, and this second entry then scratched out with an explanatory quia supra - that I realized she might have confounded the constable of Ponteland because she was both a householder and a singlewoman. There is much to appreciate and admire in databases like the EIDB. Their creation is highly productive-good for external funding, good for public impact, and good for employing early career scholars. Once they are placed online, these databases speed and enrich our work, but only as long as we use them with appropriate care and caution. 52

As to Scottish immigrants in the English North in 1440, they were a scruffy bunch: few skilled workers; few settled families; many singletons moving alone or in casual groups; many women, especially many women unattached to men. From a Scottish perspective, these emigrants look much more humble than the many

50 These corrections might eventually be incorporated into the EIDB, but in the meantime: EIDB\#5937 (John Story is a non-householder); EIDB\#7668 (Joan, not John Scot); EIDB\#7575 (Essewynus is a male forename); EIDB\#8730 (Joan, not John Tomson); TNA, E179/158/74, m. 2, John Watson has been missed between John Wright (EIDB\#7840) and Maria Scot (EIDB\#7842). Because corrections improve accuracy but create new versions, they raise new challenges for digital records like the EIDB.

${ }^{51}$ In the EIDB, https://www.englandsimmigrants.com/person/6713, accessed 18 September 2016.

${ }^{52}$ For an introduction to digital humanities more generally, see Eileen Gardiner and Ronald G. Musto, The Digital Humanities: A Primer for Students and Scholars (Cambridge, 2015). 
better-trained, better-funded, and mostly male Scots who poured into Ireland, northern Europe, and southern England in the later Middle Ages. Yet, although these Scots in England in 1440 look distinctive among Scottish emigrants, they are familiar in another context: they are much like Scottish internal migrants who can be observed in later and better-documented centuries. As Rab Houston and Ian and Kathleen Whyte have shown, Scottish internal migrants in the seventeenth and eighteenth centuries moved in much the same ways as these fifteenth-century immigrants had done: most early modern migrants were singletons; women moved farther and more frequently than men; and women found work more often in towns than in the countryside..$^{53}$

These Scots immigrants also offer us clues about how English men and women moved about the medieval countryside. The archive of medieval England is rich but focused on the relatively rich; it tells us a lot about the rents, responsibilities, and revenues of settled tenants and landowners but not much at all about the people (and especially the women among these people) who, like the Scots reported in 1440, were without land, on the move, and looking for work by day or season. These Scots traveled along English roads, settled in English communities, and worked for English employers. ${ }^{54}$ If many of them came, as is likely, from the Scottish borders, they even moved to some extent within a common border culture that, no matter how riven by raids and wars, shared distinctive customs and economies: shielings for summer pasture; salt-making along the coasts; reliance on cattle-raising and droving; mining; and perhaps even as early as the fifteenth century, a readiness to hire servants in male-female pairs, whether married or not. The English North certainly had its own traditions of landless laborers, many women among them. In Cumberland, Northumberland, and Durham c. 1300, they were called selfodes, and although their history is obscure, we now know that women sometimes, perhaps usually, predominated among them. These selfodes had their counterparts elsewhere in thirteenth-century England. On many manors across southern England, poor, landless garciones had to pay a few pennies each year on their meagre earnings. Some women paid these fines too (and some were even called garciones), but most women earned so little that they escaped this levy-they and their wages were literally beneath notice. In East Anglia, the local equivalent of selfodes and garciones were anilepimen - a term that described poor, landless, unmarried workers. So many of these anilepimen were female that clerks sometimes used a female-specific form of the word-anilepiwomen. ${ }^{55}$

In 1885, E. G. Ravenstein, the founder of modern migration studies, included in his still-revered laws of migration this unequivocal rule: "Woman is a greater migrant

${ }^{53}$ R. Houston, "Geographical Mobility in Scotland, 1652-1811: The Evidence of Testimonials," Journal of Historical Geography 11, no. 4 (October 1985): 379-94; Ian D. Whyte and Kathleen A. Whyte, "The Geographical Mobility of Women in Early Modern Scotland," in Perspectives in Scottish Social History: Essays in Honour of Rosalind Mitchison, ed. Leah Leneman (Aberdeen, 1988), 83-106.

${ }^{54}$ For similarities in migration within the two realms after 1500, see Ian D. Whyte, "Migration in EarlyModern Scotland and England: A Comparative Perspective," in Migrants, Emigrants and Immigrants: A Social History of Migration, ed. Colin G. Pooley and Ian D. Whyte (London, 1991), 87-105.

55 Judith M. Bennett, "Women and Poverty: Girls on Their Own in England before 1348," in Peasants and Lords in the Medieval English Economy: Essays in Honour of Bruce M. S. Campbell, ed. Maryanne Kowaleski, John Langdon, and Phillip R. Schofield (Turnhout, 2015), 299-323. 
than man."56 If you are surprised by this rule, you have good reason: studies of medieval and early modern migration in England sometimes ignore women altogether, often assume that most female migration was generated by relocation at marriage, and almost never understand migration as a female-led phenomenon. ${ }^{57}$ Yet running across the centuries of premodern English history is a common pattern that links poverty to women, and poor women to mobility. Women were predominant among the selfodes and anilepimen in the late thirteenth century; women proliferated among footloose workers compelled unwillingly into employment in the late fourteenth century; 58 working women from Scotland poured into fifteenthcentury England; women abounded among the mobile working poor in the sixteenth and seventeenth centuries; ${ }^{59}$ and at any moment between 1300 and 1800, migrant women could usually be found crowded into England's cities and towns in greater numbers than men. Migration for women was especially difficult and dangerous, but women-driven by poverty, expulsion, desperation, illegitimate motherhood, and sometimes even hope and aspiration-took to the road, again and again. When we contemplate the history of English migration, we should think less about provincial boys who made their fortunes in London and more about women like the two nameless ancille from Scotland who found brief employment

${ }^{56}$ E. G. Ravenstein, "The Laws of Migration," Journal of the Statistical Society of London 48, no. 2 (June 1885): 167-235; and E. G. Ravenstein, "The Laws of Migration," second paper, Journal of the Statistical Society of London 52, no. 2 (June 1889): 241-305, at 169. Using the 1881 census, Ravenstein noted that although men moved more frequently between the countries of the United Kingdom, women moved more frequently within each country.

${ }^{57}$ Bridget Hill made this point in 1994 in her "Rural-Urban Migration of Women and Their Employment in Towns," Rural History 5, no. 2 (October 1994): 185-94. The problem of male focus applies to migration studies in general, not just migration history: Monica Boyd and Elizabeth Grieco, "Women and Migration: Incorporating Gender into International Migration Theory” (Washington, DC, 2003) available online at http://www.migrationpolicy.org/article/women-and-migration-incorporating-genderinternational-migration-theory, accessed 18 April 2017. For a recent survey of the benefits of attending to gendered aspects of the history of migration, see A. James Hammerton, "Gender and Migration," in Gender and Empire, ed. Philippa Levine (Oxford, 2007), 156-80. For studies that focus on female migrants in the Middle Ages, see Grethe Jacobsen, "Female Migration and the Late Medieval Town," in Migration in der Feudalgesellschaft, ed. Gerhard Jaritz and Albert Müller (Krems, 1988), 43-55; Sharon Farmer, "Down and Out and Female in Thirteenth-Century Paris," American Historical Review 103, no. 2 (April 1998): 345-72; Sharon Farmer, The Silk Industries of Medieval Paris: Artisanal Migration, Technological Innovation, and Gendered Experience (Philadelphia, 2016); Goldberg, "Marriage, Migration and Servanthood"; Goldberg, "Migration, Youth and Gender"; Anne Reiber DeWindt, "Leaving Warboys: Emigration from a Fifteenth-Century English Village," in Writing Medieval Women's Lives, ed. Charlotte Newman Goldy and Amy Livingstone (New York, 2012), 85-111.

${ }^{58}$ Bennett, "Compulsory Service."

${ }^{59}$ For a rural example, see Tim Wales, "'Living at Their Own Hands': Policing Poor Households and the Young in Early Modern Rural England," Agricultural History Review 61, no. 1 (June 2013): 19-39. For an urban example, see Adam Crymble, Adam Dennett, and Tim Hitchcock, "Modelling Regional Imbalances in English Plebeian Migration to Late Eighteenth-Century London,” Economic History Review, http:// onlinelibrary.wiley.com/doi/10.1111/ehr.12569/abstract, esp. table 1. Earlier studies found fewer women: A. L. Beier, Masterless Men: The Vagrancy Problem in England, 1560-1640 (London, 1985); Paul A. Slack, "Vagrants and Vagrancy in England, 1598-1664," in Migration and Society in Early Modern England, ed. Peter Clark and David Souden (London, 1987), 49-76. Gender ratios depend heavily on sources; see, for example, Paul Griffiths, "Masterless Young People in Norwich, 15601645," in The Experience of Authority in Early Modern England, ed. Paul Griffiths, Adam Fox, and Steve Hindle (Houndmills, 1996), 146-86. 
with Robert Bate in Glassonby in August 1440 and were gone by November. What Ravenstein observed in the nineteenth century was true for the centuries that preceded him. The tracks and roads of traditional England were full of people who, no matter what their realm of birth, were looking for work. Most were single folk, prepared to move again and again, and numerous among them-and often the most mobile among them-were women, most of them singlewomen. 